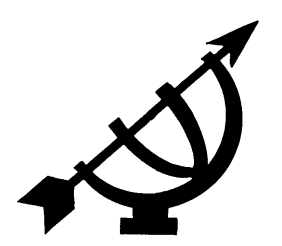

\title{
Die integrasie van humoristiese tekste by taalonderwys om studente se emosionele geletterdheid te ontwikkel: 'n gevallestudie ${ }^{1}$
}

\author{
E. Kruger \& L. Rutgers \\ Departement Kurrikulumstudie \\ Universiteit van Stellenbosch \\ STELLENBOSCH \\ E-pos: ekruger@sun.ac.za \\ Irutgers@sun.ac.za
}

\begin{abstract}
The integration of humorous texts in language education to develop students' emotional literacy: a case study

The integration of humorous material in language teaching can be instrumental in the development of emotional literacy, thereby fostering an aesthetic sensitivity in student teachers (as learners) in different social contexts. Texts containing humour can play a significant role in the development of learners' understanding and appreciation of a language, as well as the cultural heritage it embodies. Furthermore, it offers learners the opportunity to become creatively and imaginatively involved with oral, visual and written texts. The article illustrates how the application of humorous material in the teaching of Afrikaans is not only rooted in responsive education, but complies with the objectives of the South African teaching policy documents.
\end{abstract}

By concentrating on a literature review of research studies, the authors point out the correlation between humour and various factors that influence learners' and students' affective behaviour in the context of the language classroom. Particular reference is made to research results indicating that the use of humour

1 Die outeurs wil besondere dank betuig aan Sarie Berkhout vir hulp met die konseptualisering, Eloïse Loftie-Eaton vir die redigering en Zandra Bezuidenhout vir die taalversorging van hierdie artikel. 
induces a more positive attitude, while also motivating students (as learners) to participate constructively in language activities. Attention is also paid to the relationship between different personality types (based on cognitive style) and anxiety. Moreover, the established link between humour and anxiety justifies the inclusion of humorous texts to reduce language-related anxiety. Ultimately the research serves to support the authors' argument in favour of incorporating humorous material in the teaching of Afrikaans, while several (practical) teaching strategies are suggested. The authors hope to enhance the educational value by pursuing a holistic approach to language teaching.

\section{Opsomming}

\section{Die integrasie van humoristiese tekste by taalonderwys om studente se emosionele geletterdheid te ontwikkel: 'n gevallestudie}

Die aanwending van humoristiese tekste om emosionele geletterdheid by die onderrig van Afrikaans te integreer, kan bydra tot die ontwikkeling van taalonderwysstudente (as leerders) se estetiese sensitiwiteit in verskillende sosiale kontekste. Dit beteken dat studente deur middel van humoristiese tekste kan leer om begrip en waardering vir tale te toon, asook vir die kulturele erfenis wat daardeur oorgedra word. Verder bied dit aan die betrokke studente geleenthede om skeppend en verbeeldingryk met mondelinge, visuele en geskrewe tekste om te gaan. Die artikel illustreer hoe die integrasie van humoristiese tekste in die onderrig van Afrikaans nie alleen 'n teoretiese begronding in responsiewe onderwys het nie, maar in ooreenstemming is met die doelstellings van die Suid-Afrikaanse beleidsdokumente.

Aan die hand van 'n literatuuroorsig konsentreer die outeurs van hierdie artikel op die verband tussen humor en verskeie faktore wat leerders se affektiewe belewenis binne die konteks van die taalklaskamer beïnvloed. Daar word op navorsingsresultate gefokus wat toon dat die gebruik van humoristiese tekste studente (as leerders) se houding en motivering om kreatief en konstruktief aan taalaktiwiteite deel te neem, kan verhoog. Aandag word ook gegee aan die verband tussen verskillende persoonlikheidstipes (op kognitiewe styl gebaseer) en humor. Die bewese verband tussen humor en angs regverdig ook die aanwending van humoristiese tekste om taalangs te verminder. Uiteindelik word met navorsingsteun gemotiveer waarom humoristiese tekste suksesvol in die onderrig van Afrikaans gebruik kan word en enkele (praktiese) onderrigidees word uitgelig. Met hierdie artikel hoop die outeurs om by te dra 
tot waarde-ontwikkeling deur middel van 'n holistiese benadering tot taalonderrig.

\section{Inleiding en probleemstelling}

$\mathrm{Na}$ aanleiding van eie onderrigervaring het die vermoede by die outeurs ontstaan dat daar 'n affektiewe filter of versperring is (vgl. Krashen, 1985) wat leerders in die ontwikkeling van hulle kreatiwiteit en taalgebruik in Afrikaans kan strem. Dit het ook in die algemeen geblyk dat taalonderwysers nie oor 'n verskeidenheid onderrigstrategieë beskik om hierdie affektiewe filter te verlaag of deur die versperring te dring nie. Die navorsingsvrae wat uit hierdie vermoede en refleksie aan die hand van die outeurs se ervaring en ontwikkeling van hulle epistemologie voortgevloei het, was eerstens hoe die huidige onderwysbeleidsdokumente sou voorsiening maak vir die gebruik van humoristiese tekste. 'n Verdere vraag wat ontstaan het, was hoe die gebruik van sodanige tekste as onderriginstrument binne die raamwerk van responsiewe onderwys (vgl. Boling \& Senokossoff, 2007) aan opvoeders 'n meganisme kan bied om die affektiewe filter in die onderrig van Afrikaans te verlaag (lees ook: om daardeur te dring) sodat leerders met meer belangstelling en betrokkenheid kan deelneem aan en groei in hulle eie kreatiewe denke en taalgebruik.

Die Suid-Afrikaanse onderwysbeleidsdokumente volg 'n inklusiewe benadering deur minimumvereistes vir alle leerders te spesifiseer. Dit gee erkenning aan die beginsel dat alle leerders deur taalonderrig die geleentheid moet kry om hulle volle potensiaal te ontwikkel. Volgens die genoemde dokumente word in die (responsiewe) ontwerp en ontwikkeling van gepaste leerprogramme aan die intellektuele, sosiale, emosionele, spirituele en fisieke behoeftes van leerders, asook aan die gebruik van gepaste assesseringsinstrumente aandag gegee (Departement van Onderwys, 2003:10). Klem word gelê op die feit dat alle tekste waardes oordra wat positief of negatief kan wees, maar dat dit nie altyd ooglopend is nie.

'n Ondersoek na die Suid-Afrikaanse beleidsdokumente vir uitkomsgebaseerde onderwys het aangetoon dat een van die ontwikkelingsuitkomste geformuleer word in terme van die ontwikkeling van die estetiese sensitiwiteit van leerders in verskeie sosiale kontekste (Departement van Onderwys, 2002; 2003). In 'n terminologieverduideliking in die Nasionale Kurrikulumverklaring vir Verdere Onderwys en Opleiding (Departement van Onderwys, 2003:49-62) word klem gelê op taal en styl wat persoonlik is, wat sterk gevoelens wek en wat die teenoorgestelde van nugtere, saaklike taal is. Verder 
word aandag gegee aan spesifieke stylfigure soos die eufemisme as versagtende uitdrukking of omskrywing, wat dien as verbloeming en wat gebruik word om gevoelens nie seer te maak nie. Die toon van 'n teks word beskryf as die klank van 'n bepaalde intensiteit, toonhoogte of stembuiging wat die gevoelsboodskap van 'n teks kan oordra. In 'n geskrewe teks word die atmosfeer (lees: gevoelens) in woorde uitgedruk, terwyl dit in films verder deur musiek of agtergrond geskep of bevestig word.

Dit is die mening van die skrywers dat die gebruik van humoristiese tekste (as kulturele uiting) kan bydra tot die emosionele ontwikkeling van taalonderwysstudente as deel van responsiewe onderwys. Deur byvoorbeeld die limeriek en parodie in taalonderrig te integreer, kan studente se estetiese persepsie en ekspressie ontwikkel word. Taalonderwysstudente kan hierdeur bewus gemaak word van "hoe hulle waardes uitdruk wanneer hulle self tekste skep - soos verdraagsaamheid, empatie, respek, genot, humor, speelsheid, ontevredenheid, woede" (Departement van Onderwys, 2002:8).

Die outeurs se argument is dat taalonderwysstudente, deur hulle blootstelling aan humoristiese tekste in 'n holistiese benadering tot taalonderrig, bewus kan word "van ... krities ... wees oor waardes in die tekste wat hulle lees, waarna hulle kyk en wat hulle self skep" (Departement van Onderwys, 2002:8). Die artikel konsentreer spesifiek op die implementering van konstruktivistiese en holistiese leerteoretiese beginsels met die oog op die opleiding van taalonderwysstudente om aan responsiewe onderwys deel te neem. Volgens Tomlinson en Eidson (2003:2) is responsiewe onderwys "a teacher's solid (and growing) understanding of how teaching and learning occur, and it responds to varied learners' needs ...".

Die argument in die artikel is dat die integrasie van humortekste in taalonderrig as ontwikkeling van kulturele geletterdheid binne die teoretiese raamwerk van responsiewe onderwys kan bydra tot die oplossing van 'n probleem wat Zins et al. (2004:5) beskryf. Hierdie probleem is dat daar tans heelwat pogings is wat die ontwikkeling van emosionele en kulturele geletterdheid gefragmenteerd hanteer (bv. aparte programme wat gesondheid bevorder; geweld, HIV en VIGS, tienerswangerskappe en jeugmisdaad probeer teëwerk; deurvloeikoerse in skoolbywoning en lojaliteit wil aanmoedig). Dit het tot gevolg dat 'n groot hoeveelheid ekstra programme en praktyke gefinansier moet word - die vraag is egter of dit werklik tot akademiese sukses bydra en of daar nie meer holisties, gekoördineerde en geïntegreerde benaderings is wat kan bydra tot motivering, selfhandhawing en kreatiwiteit van leerders nie. 'n Verdere motivering 
vir die gebruik van humoristiese tekste in taalonderrig kan ook gevind word in Zins et al. (2004:10) se voorbeelde van effektiewe SEL-programme (sosiale en emosionele leerprogramme) wat spesifiek op die aanmoediging van aktiewe deelname fokus; die gebruik van uiteenlopende, interaktiewe onderrigstrategieë wat leerders betrek en motiveer; sowel as (tekste en) aktiwiteite wat kulturele sensitiwiteit en respek vir diversiteit beklemtoon.

In hierdie artikel wil die outeurs veral aandag gee aan die integrasie van humoristiese tekste by taalonderrig as inhoud sowel as onderrigstrategie, om die student se (affektiewe) omgewing te verryk en hierdeur die ontwikkeling van emosionele geletterdheid te fasiliteer. Daarmee saam wil die outeurs 'n beskrywing gee van 'n gevallestudie as voorbeeld van responsiewe onderwys (vgl. Boling \& Senokossoff, 2007). Hierin was die fokus gerig op die verryking van onderwysstudente se affektiewe ervaring in taalonderrig deur middel van die integrasie van humoristiese tekste. In hierdie onderrigprogram is ' $n$ verskeidenheid tekste ingesluit om leesmotivering en kritiese geletterdheid binne 'n emosioneel-veilige omgewing aan te moedig. Die taalleeromgewing was met stimulerende leerervarings gevul om die taalinhoud met humoristiese onderrigmateriaal te verryk. Die onderrigprogram is deur middel van formatiewe assessering gemonitor asook onderrigstrategieë wat gebaseer is op die behoeftes, kennis en vaardighede van onderwysstudente as leerders binne die kulturele konteks van Afrikaans.

Vervolgens word die integrasie van die affektiewe en humor in taalonderrig bespreek aan die hand van 'n literatuuroorsig en 'n kort beskrywing van die navorsingsprogram. As motivering vir die integrasie van die affektiewe en humor in taalonderrig, word eerstens op die begrip responsiewe onderwys gekonsentreer.

\section{Die integrasie van die affektiewe en humor in taalonderrig}

Responsiewe onderwysers poog om uitgebreide kennis oor kinders en die leerproses in te win, sodat hulle goed toegerus kan wees om toepaslike onderrigmetodes in verskillende onderrigsituasies toe te pas. Die outeurs, as responsiewe opvoeders, glo dat die klaskamer in 'n aangename leeromgewing omskep moet word waarin alle leerders aanvaar en as waardevol geag word ongeag hulle individuele verskille. 


\subsection{Responsiewe onderwys}

Boling en Senokossoff (2007) meen dat responsiewe onderwysers gelei word deur die integrasie van vier onderrigelemente, naamlik die student (gender, kultuur, kognitiewe vermoëns en sosiale vaardighede), die omgewing (verskeidenheid tekste, leesmotivering en geletterdheid binne 'n emosioneel-veilige omgewing gevul met leerervarings), die inhoud (verrykte onderrigmateriaal en -omgewings met leer wat deur middel van formatiewe assessering gemonitor word) en die onderrig (gebaseer op die behoeftes van die samelewing en die kennis en vaardighede van leerders).

Gay (2000) se definisie van kultureel-responsiewe onderwys fokus op die belangrikheid van diverse leerders se kulturele kennis, lewenservarings en voorkeurleerstyle om die toepaslikheid en effektiwiteit van onderrig en leer te verseker. Die National Center for Mental Health Promotion and Youth Violence Prevention (Chicago, VSA) maak dit duidelik dat sosiale en emosionele vaardighede leerders se sosiale bewussyn insluit - met ander woorde leerders wat individuele en groepsooreenkomste en -verskille kan onderskei en waardeer, interpersoonlike konflik kan voorkom, hanteer en konstruktief oplos en respek vir die gevoelens van ander kan toon; kan onderskei tussen onbewuste en doelbewuste disrespek. Dit is kommunikatiewe vaardighede wat leerders kan help om die moontlikheid van ontoepaslike, provokatiewe aggressiewe response wat tot interpersoolike konflik of portuurverwerping kan lei, te voorkom en te vermy.

Vroeër is die term affektiewe (humanistiese) onderwys in hierdie verband gebruik (Legutke \& Thomas, 1991). Daar was sedert die sewentigerjare van die vorige eeu (veral in Amerika) 'n groeiende bewuswording van holistiese klaskamertegnieke en ervaringsleer wat op leerdergesentreerdheid berus en die betrekking van die hele persoon by die onderrigproses bevorder (Legutke \& Thomas, 1991:47; Williams \& Burden, 1997:38; Graczyk et al., 2000:399). Hierdie beweging het as affektiewe (humanistiese) onderwys bekend gestaan en is later vervang met die konsep van responsiewe onderwys.

Affektiewe onderwys lê veral klem op die onderrig van vaardighede om aan te pas by sowel emosionele as intellektuele uitdagings, en ' $n$ dinamiese balans tussen denke, gevoelens, optrede en kreatiwiteit (Legutke \& Thomas, 1991:40-47). Hierdie soort onderwys sluit sensitiwiteitsopleiding en selfkennis in, sowel as die bewussyn, waarneming en die emosionele welstand van die leerder. Sodanige pro- 
gramme gaan van die standpunt uit dat die leerproses 'n empatieke gesprek met jou leefwêreld is waarin tegnieke vir liggaamlike ontspanning, die psigodramatiese uitdrukking van gevoelens en die ontwikkeling van empatie beoefen word. Verder word in hierdie programme veral aandag aan kommunikasievaardighede, die stimulering van die verbeelding, projeksie en kreatiwiteit gegee.

Hierdie artikel wil vanuit 'n ontologiese perspektief, wat die wetenskap van ons menswees in die algemeen beklemtoon, aspekte soos die wesenlikheid van leerders se bestaan en realiteite uitlig. Dit is belangrik om leerders se daaglikse leef- en leeromgewings sodanig in te rig dat leerfasiliteerders hulle vlak van swaarkry kan verlig en aan die leerders geleenthede kan bied om 'n vervullende en gelukkiger bestaan te voer. In hierdie artikel word dit dus beklemtoon hoe verskillende pogings aangewend kan word om die leerinhoud vir leerders meer relevant, interessant en genotvol te maak. Die leerder se behoefte om te behoort, word sterk deur affektiewe (lees: responsiewe) onderwys beklemtoon. Spesifieke klem word gelê op die ontwikkeling van persoonlike identiteit deur die minimalisering van kritiek (omdat "foute" gesien kan word as 'n integrale deel van die leerproses volgens konstruktivistiese en holistiese leerteorieë; vgl. Poplin, 1988:409,412; Oxford, 1997:54; Rasmussen, 2001:577; Lesh et al., 2003:218), en die ontwikkeling van 'n metabewustheid van die leerproses. Die doel met die genoemde onderrigstrategieë is veral om leerders toe te laat om keuses te maak, en hulle aan te moedig om verantwoordelikheid vir die eie leer te aanvaar deur middel van selfontwikkeling en -evaluering (Legutke \& Thomas, 1991:47; Williams \& Burden, 1997:38).

In die tersaaklike navorsingsprogram was dit nodig om vas te stel watter bevindings reeds deur verskeie navorsers en teoretici oor die gebruik van humor in die onderrigproses gedokumenteer is. 'n Literatuurstudie het belangrike resultate opgelewer, wat vervolgens bespreek sal word.

\subsection{Literatuuroorsig}

Humor kan lewensgehalte en die proses van taalonderrig verbeter. Pollak en Freda (1997) is van mening dat die gebruik van humor in onderrig tot doeltreffende leer kan bydra. Die funksies van humor in die onderrig- en leersituasie kan opgesom word as die opbou van verhoudings, bemagtiging van leerders, kreatiewe denke, stimulering van belangstelling, opbou van selfbeeld en sosialisering om houdings (gesindhede en waardes), motivering, leerderoutonomie en selfwerksaamheid (Aoki, 1999) te bevorder. 
Kher et al. (1999) beweer dat humor 'n waardevolle onderriginstrument is om 'n klaskameratmosfeer te skep wat leer interessanter maak en gevolglik kan bevorder. Hulle beklemtoon die feit dat geskikte en gepaste humor onderlinge openheid en respek kan bewerkstellig. Daarby verwys hulle na navorsingsgetuienis in verband met die verhouding tussen onderwyser en leerder, en dat entoesiasme en humor aansteeklik kan wees (Kher et al., 1999). Die onderwyser se sin vir humor kan ook daartoe bydra dat leerders ontspan en minder angs ervaar, soos aangetoon in studies oor die sogenaamde "ingewikkelde" vakke soos wiskunde, natuurwetenskap en statistiek (Bryant et al., 1979; Kher et al., 1999).

Lyttle (2001) meen onderwysers behoort daarvan kennis te neem dat ironiese humor in spotprente meer doeltreffend is en dat selfspottende (self-effacing) humor die beste uitwerking op leerders in die klaskamerkonteks het. Ook Berk (1998:47), 'n professor in statistiek aan die Johns Hopkins Universiteit, maak suksesvol van selfspot gebruik. Hy meen dat dit die studente (by implikasie ook taalonderwysstudente) aanmoedig om die onderriggewer as toeganklik te ervaar. Die gebruik van humoristiese tekste kan ook skaam studente en leerders aanmoedig om deel te neem, omdat dit hulle vrees om foute te maak, verminder (Pollak \& Freda, 1997; Chiasson, 2002).

Dewitte en Verguts (2001:40) beweer dat 'n sin vir humor daaruit bestaan dat iemand grappe kan genereer en sensitief is vir die sosiale omgewing. Hulle meld dat daar ' $n$ verband tussen ekstroversie en humorproduksie is. Verskeie navorsers maak aanbevelings oor hoe onderwysers hulle sin vir humor kan ontwikkel (Berk, 1998; Chiasson, 2002; Ulloth, 2003:35-36; Torok et al., 2004).

Voordat die begrip emosionele geletterdheid meer breedvoerig bespreek word, maak die outeurs eers kortliks melding van die navorsingsprogram waarna in die artikel verwys word.

\subsection{Navorsingsprogram: 'n gevallestudie}

Die navorsing is vanuit 'n kwalitatiewe perspektief benader met die doel om die taalonderwysstudente as leerders se subjektiewe ervaring van die leerproses beter te verstaan. Die ondersoek was aanvanklik eksploratief en uiteindelik beskrywend. 'n Kwalitatiewe benadering is gevolg, en die beskrywing en bespreking van 'n gevallestudie was die spesifieke navorsingstrategie. 
Die navorsing is gedoen met dertien aspirantopvoeders wat hulle voorberei het om Afrikaans in hoërskole te onderrig. Hierdie onderwysstudente het Afrikaans as spesialiseringsrigting vir die Nasionale Onderwyssertifikaat ('n nagraadse kwalifikasie) aan die Universiteit van Stellenbosch gekies. Hulle is deur die module, Kurrikulumstudie Afrikaans, toegerus om Afrikaans aan moedertaalsprekers sowel as addisionele-taalleerders in die Algemene Onderwys en Opleidingsfase (grade 7 tot 9) en ook Verdere Onderwys en Opleidingsfases (grade 10 tot 12) op skool te onderrig. Die rede vir die insluiting van hierdie groep was om vas te stel hoe hierdie onderwysstudente op die humoristiese tekste wat gebruik is, sou reageer en wat die opvoedkundige waarde van humor as onderriginstrument is. Die materiaal, aktiwiteite en proses wat vir die taalonderrigstudente se ontwikkeling en professionele opleiding gekies is, is beskryf. Verder is die teikengroep se kreatiewe taaluitings met humoristiese tekste as stimulus (limerieke en parodieë) ook waargeneem, ontleed en beskryf, refleksie oor die proses is voortdurend opgeteken, en uiteindelik is patrone, temas en verduidelikings geanaliseer (Babbie \& Mouton, 2001:283) om veralgemenings te vind.

Ter wille van betroubaarheid en geldigheid in die kwalitatiewe ondersoek is veelvuldige databronne in die navorsingsgebeure gebruik (Lather, 1986; Denscombe, 1998). Hierdie databronne sluit die refleksie van bogenoemde onderwysstudente in, asook verslae van portuurlesers, onderhoude met onderwysstudente en portuurlesers, vraelyste aan onderwysstudente en portuurlesers, die onderwysstudente se parodietekste en onderrigprogramme by skole.

Om die data in te samel, is die beginsels van kwalitatiewe beskrywing van 'n gevallestudie geïmplementeer en rekord gehou van die hele proses. Die kwalitatiewe data is op verskeie maniere gedokumenteer. In die onderhawige studie is die data-insamelings- en -genereringsproses soos volg uitgevoer waar die betrokke studente aan verskeie onderrigfases deelgeneem het:

In die eerste fase is humoristiese tekste as onderriginstrument in die onderskeie lesings gebruik, met gepaardgaande tekste en aktiwiteite vir taalonderrig ten opsigte van Afrikaans as huistaal en as addisionele taal, en daar is voortdurend daaroor gereflekteer. Vir doeltreffende onderwys binne elke deelnemende aspirantopvoeder se bepaalde onderrigkonteks tydens skoolbesoek was dit in die tweede fase nodig dat hulle individueel 'n gepaste lesprogram met humoristiese tekste as onderriginstrument (volgens eie keuse) ontwerp en gebruik. Die derde fase het behels dat studente individueel en in 'n groepsonderhoud oor die gebruik van humoristiese tekste in die 
taalklaskamer reflekteer. Mettertyd het ' $n$ vierde fase van datagenerering plaasgevind toe daar tydens die ontleding van die onderwysstudente se parodietekste gevind is dat dit nodig is om met portuurlesers as dekodeerders van hierdie tipe tekste te kommunikeer. Die vrae wat in die onderhoude gebruik is en om te bepaal hoe hulle die parodietekste ontleed het, is ook gedokumenteer. Tydens die laaste fase het die studente aan 'n rekenaarondersteunde taalonderrigprogram en 'n webgebaseerde rolspeldebat deelgeneem.

Vir data-analise is die insameling, kategorisering en vergelyking van data deurlopend deur middel van dataredusering (Miles \& Huberman, 1994) ontleed en kritiese refleksie is gedoen om sodoende relevante temas en patrone te identifiseer (Lather, 1986). Op grond van die resultate is afleidings oor die bruikbaarheid van humoristiese tekste in die onderrig van Afrikaans gemaak. Die parodieë wat die studente geskryf het, is ontleed volgens kategorieë wat inherent deel van die intertekstualiteit en kontekstualiteit van die parodietekste was (vgl. Denzin \& Lincoln, 2005:4).

Vervolgens word ' $n$ bespreking van emosionele geletterdheid wat as kernkonsep in hierdie artikel gebruik word, verskaf om hiermee inligting vanuit die psigolinguistiek en sosiolinguistiek te ekstrapoleer en dinamies te verweef soos wat dit in die navorsingsprogram geïntegreer is as deel van responsiewe onderwys.

\section{Begripsomskrywing: emosionele (affektiewe) geletterdheid}

In hierdie artikel word die term emosionele geletterdheid (Barnard \& Herbst, 2005:54-5; Park, 1999:20; De Wit, 2002) as wisselterm gebruik om na emosionele intelligensie te verwys, wat volgens Olivier (2005:346) beteken: “. $\ldots$ the ability to sense, understand, and effectively apply the power and acumen of emotions as a source of human energy, information, connection and influence". Selfbewussyn vorm volgens Goleman (1996:43) die kern van emosionele intelligensie en dra by tot die persoon se kennis van die eie emosies en gevolglike selfbeheer. Ander komponente wat deur Goleman (aangehaal in Olivier, 2005:346) as deel van emosionele intelligensie geïdentifiseer word, is die vermoë om die eie gevoelens gepas te beheer, empatie te hê met die emosies van ander mense in die omgewing, effektiewe doelnastrewing en motivering deur middel van kreatiwiteit.

Die term affek dui op aspekte van die mens se emosionele belewenisse. Die onderwyser se fasiliteringstyl, emosionele geletterdheid, 
houding teenoor die leerders, sowel as affektiewe faktore, individuele leerstyle en die meervoudige intelligensies van die leerders bepaal die klaskameratmosfeer (Goleman, 1996; Underhill, 1997; Arnold \& Brown, 1999:3-4; Shepard et al., 1999). Volgens Goleman (1998:318) bestaan emosionele intelligensie uit selfbewussyn, motivering, selfregulering, empatie en sosiale vaardigheid (aanpasbaarheid) in verhoudings.

Emosionele intelligensie soos deur Mayer en Salovey (1993) gedefinieer, fokus op vier areas van emosionele bevoegdheid, naamlik die akkurate waarneming van emosies, die benutting van emosies om denke en leer te fasiliteer, die vermoë om die betekenis van emosies te verstaan en om emosies te bestuur. Emosionele geletterdheid behels dus die psigodinamiese proses van herkenning, kennis en gebruik (beheer) van emosies as deel van selfaktualisering en produktiwiteit. Gardner (1991) integreer ook emosionele geletterdheid as hy na intra- en interpersoonlike intelligensie verwys. Vir die doel van hierdie artikel sal die affektiewe as term gebruik word vir aspekte van emosie, houding, motivering, angs en persoonlikheidsaspekte wat 'n invloed op die taalonderrigsituasie het.

Verskeie navorsers is van mening dat die funksionering van 'n mens se kognitiewe domein (kritiese denke, probleemoplossing, leer) sterk deur die affektiewe domein beïnvloed word (Bodenstein, 1998:276; Hugo, 2001:139). Die affektiewe domein behels gevoelens, emosies, houdings, belangstellings, waardering, waardeoordele, selfkonsep en motivering. Damasio (aangehaal in Arnold \& Brown, 1999:1-2) onderskei tussen emosies (veranderings in die liggaam as reaksie op 'n positiewe of negatiewe situasie) en gevoelens (waarneming van hierdie veranderings). Navorsingsgetuienis toon dat breinfunksionering (veral die regtervoorbrein en die limbiese stelsel) met betrekking tot die affektiewe, 'n bepalende faktor is in motivering, aandagspan en kognitiewe funksionering (Caine \& Caine, 1991; Stevick, 1999; Jensen, 2000; Roberts, 2002).

In hierdie artikel word nie op spesifieke (teoretiese) verskille tussen die onderrig van 'n huistaal en 'n addisionele taal ingegaan nie. Die argument is dat humoristiese tekste die blokkasies, wat as gevolg van enige affektiewe hindernis kan ontstaan, in die taalonderrigsituasie kan verminder. Daar is verskeie affektiewe faktore wat 'n fasiliterende of inhiberende rol in taalonderrig speel. Affektiewe faktore wat taalleer kan inhibeer, sluit egosterkte, foute, angs, kompetisie, geheueprobleme, negatiewe houding, swak motivering en belangstelling, introversie, lae selfkonsep en selfaktualisering in 
(Farley, 1981; Arnold \& Brown, 1999; Ehrman, 1999; Stevick, 1999; Hugo, 2001).

Krashen (1985:3) gebruik 'n metafoor in sy beskrywing van die affektiewe as 'n filter in taalonderrig (McLaughlin, 1987:50; Crookes, 1992:435). Volgens Krashen kan 'n negatiewe affektiewe disposisie die verstaanbare taaltoevoer verhinder. Juis daarom is 'n positiewe affektiewe toestand noodsaaklik vir die doeltreffende ontwikkeling van taal en kreatiewe denke. Affektiewe weerstand behels 'n gebrek aan motivering, ' $n$ lae selfbeeld en angs wat prestasie teenwerk. 'n Kombinasie van negatiewe faktore kan die affektiewe filter laat toeneem en 'n intellektuele blokkasie vorm, wat kan veroorsaak dat die leerder 'n gebrek aan belangstelling in die taalonderrigproses toon. Mulligan (1993:46) sluit hierby aan en beskryf sy model van ervaringsleer wat op sewe kategorieë (denke, gevoel, aanvoeling, intuïsie, herinnering, verbeelding en wil) gebaseer is, en wat die belangrike rol wat die affektiewe in die leerproses speel, verduidelik.

Die outeurs argumenteer dat die integrasie van humoristiese tekste in taalonderrig aan die vereistes van die holistiese benadering tot onderrig voldoen en as implementering van responsiewe onderwys tot affektiewe, estetiese en kulturele waarde-ontwikkeling kan bydra. Vervolgens word 'n literatuuroorsig gebied wat handel oor die verband tussen humor en verskeie affektiewe belewenisse wat taalonderrig aan onderwysstudente kan beïnvloed.

\subsection{Die affektiewe en humor}

In haar studie oor die verband tussen kognitiewe buigsaamheid en humorsin meld Pienaar (2004:4-5) verskeie navorsingsresultate oor humorkenmerke wat wys op 'n verband tussen humor en die affektiewe. Sy verwys na 'n multidimensionaliteit van elemente waaruit humor bestaan: humoristiese stimuli (byvoorbeeld grappe, poetse, strokiesprente en komedierolprente, fisiese en visuele humor, asook mimiek, pittige en gevatte opmerkings, stories, anekdotes, karaktersketse en metafore, dubbelsinnighede), humoristiese response (lag of glimlag, vreugde, verrassing), gesindheid (meegevoel, deernis en/of goedgunstigheid), intra-psigiese en interpersoonlike vlakke, asook verryking en terapie (wat bydra tot die mens se emosionele gesondheid).

Die outeurs is van mening dat die affektiewe filter (Krashen, 1985) deur middel van humoristiese tekste verlaag (lees: deurdring, verminder) kan word, omdat onderwysstudente hulle emosionele probleme kan oorkom deur daaroor te lag (Engelbrecht, 1990:95, 96). 
Verskeie studies toon dat humor terapeuties kan wees in die sin dat dit spanning en angs kan verlig (Martin \& Lefcourt, 1983; Abel, 2002). Verder vind Kuiper et al. (1995:359) dat humoristiese tekste as 'n positiewe hanteringsmeganisme vir spesifieke streselemente soos eksamens, gebruik kan word, omdat daar 'n kognitief-affektiewe skuif plaasvind. Die gebruik van humor kan 'n mens ook aanmoedig om bewustelik na alternatiewe perspektiewe tot probleme te soek. Op hierdie wyse bevorder humor dus kreatiewe denke (Ziv, 1984; Chiasson, 2002).

Die skep van humor kan daartoe bydra om depressie te verminder. Freheit en Overholzer (1998:32) meld studies wat aantoon dat humor 'n doeltreffende hanteringsmeganisme vir 'n verskeidenheid emosies is. Humor word met verminderde gevoelens van angs en spanning verbind. Ook die humor van komiese kreatiwiteit in teater, films en grappe kan die kyker/luisteraar van angs, aggressie en onderdrukking bevry wat daagliks ervaar word. Humorervaring kan ook tot beter kognitiewe funksionering lei. Verder kan die humorervaring daartoe lei dat die humorgebruiker sterker outonomie (agentskap) ervaar, doelwitte meer doeltreffend bereik (Kuiper et al., 1995; Martin et al., 2003:9) en beter kommunikeer (Wycoff \& Pryor, 2003:41).

Uit die refleksie van onderwysstudente in die navorsingsprogram blyk dit dat hulle van mening is dat die genoemde skryfoefeninge (limerieke en parodieë) kan bydra om leerderbetrokkenheid in taalonderrig te bewerkstellig en te behou, en dat leer dus meer effektief kan wees. Een student het spesifiek gemeld dat dit pret was om klas toe te kom, hoewel dit by hom die vraag laat ontstaan het hoe hy in die praktyk self humoristiese tekste sou gebruik (waarskynlik omdat die beleidsdokumente nie noodwendig die belang van humoristiese tekste in die taalklaskamer eksplisiet aanstip nie). Vir hierdie student was dit egter wel van belang dat die integrasie van humoristiese tekste effektief in die onderrigprogram gedemonstreer is en dat die verskillende tipes skryfwerk sy eie kreatiwiteit gestimuleer het. Laasgenoemde is ook iets waarvan studente meermale gewag gemaak het, naamlik dat hulle aanvanklik self min woorde gehad het om by te voeg (wat tot frustrasie gelei het), maar dat die sinergie in die klasgroep en ander studente se kreatiwiteit hulle met (aangename) verbasing na hulle eie eindprodukte laat kyk het.

Een van die studente wat reeds vroeër self kreatiewe skryfprodukte gelewer het, het opgemerk dat dit vir 'n haar 'n verrassing was om te sien hoe humor nuwe sprankel (oemf) in haar skryfwerk gesit het. 'n Ander student het spesifiek geskryf dat sy graag as onderwyser 'n humoristiese verhouding met leerders sou wou bou, sodat hulle 
meer kan ontspan en leer om vir hulleself te lag, en nie te ernstig te wees nie. Verskeie studente het daarvan melding gemaak dat die integrasie van humoristiese tekste in die onderrigprogram hulle toegelaat het om weer kind te wees en dat dit 'n ontspanne klaskameratmosfeer geskep het.

Meer as een student het opgemerk dat die leerproses aangenaam was en dat hulle eintlik nie gevoel het dat hulle leer nie, aangesien leer gewoonlik "nie lekker is nie". Dit het ook duidelik na vore gekom dat die pikturale (visuele) humor in die spotprente beslis die potensiaal het om kognitiewe prosesse te stimuleer, te ontwikkel en kommunikasie te bevorder.

Vervolgens word op die verband tussen enkele aspekte van die affektiewe as deel van emosionele geletterdheid gekonsentreer: houding (gesindheid en motivering), persoonlikheid (kognitiewe styl), angs en humor. Daarna sal op enkele kulturele faktore gefokus word om die invloed van humor op kulturele geletterdheid in die taalklaskamer uit te lig.

\subsubsection{Houding (gesindheid), motivering en humor}

Leerders wat nie in die leersituasie geborge voel nie, sal nie 'n waaghouding in hulle leerwerk openbaar nie en kan hulle gevolglik aan die situasie onttrek (Gardner, 1985). Booyse (1992:62-90) maak melding van vier kenmerkende funksies wat aan houding toegeken kan word, naamlik die kennisfunksie, die instrumentele (handelings-) funksie, die waarde-ekspressiefunksie en die egobeskermende funksie. Affektiewe faktore het hiervolgens 'n direkte invloed op die houding wat leerders teenoor die vakinhoud en leer openbaar.

Scharle en Szabó (2000:48) voer aan dat houding direk verband hou met leerders se gemotiveerdheid om aan die leerproses deel te neem. Hulle beklemtoon die belangrikheid van leerders se belangstelling in die vak, sowel as die ontwikkeling van hulle selfbeeld, deur middel van kreatiewe aktiwiteite waarin hulle hulle persoonlike ervaring en nietalige kennis kan gebruik. Hugo (2001:140) bespreek die affektiewe komponente wat met lees en studeer verband hou. Sy argumenteer dat 'n persoon se houding teenoor dit wat gelees word ' $n$ mobiliseerder of immobiliseerder kan wees wat bepaal of die persoon 'n sekere leeshandeling sal begin en voltooi. 
Die outeurs meen dat daar dissiplineprobleme in die klaskamer kan ontstaan as gevolg van adolessente se uitdrukking van humor. ${ }^{2}$ Hierdie probleme gaan dikwels gepaard met leerders se houding en gevoelens van frustrasie (vgl. Dreyer, 2005:24 wat die noodsaak daarvan beklemtoon dat onderwysers alternatiewe interaksiemetodes behoort te soek om leerders se emosionele behoeftes te hanteer). Ziv (1988:359) verwys na die frustrasie-aggressiehipotese wat verklaar waarom adolessente negatief optree of akademies misluk. In sy studie met graad 11- en 12-leerders, toon Ziv aan dat die gebruik van humoristiese tekste die neiging tot aggressiewe response in gefrustreerde adolessente verminder (Ziv, 1988:363).

'n Verdere bespreking van motivering in taalonderrig is relevant, omdat die argument in hierdie artikel is dat humoristiese tekste kan bydra tot 'n sterker motivering by onderwysstudente om aan die onderrigproses deel te neem. 'n Ondersoek deur White (2001:345) toon dat onderwysers van mening is dat hulle gebruik van humor tot die leerders se motivering bydra en denke bevorder. Met betrekking tot humor en houding wys Martin et al. (2003:49) daarop dat humor tot 'n positiewe houding teenoor die lewe en leerervarings kan bydra.

Die navorsing deur Kuiper et al. (1995:368) het bevind dat deelnemers se sin vir humor en hulle gevolglike positiewe benadering hulle nuuskierigheid en motivering om nuwe take aan te pak en deur te voer, fasiliteer. Humor kan dus gebruik word om taalonderwysstudente se nuuskierigheid te prikkel deur hulle belangstelling te wek, omdat humor kan bydra tot 'n verskuiwing in kognitiefaffektiewe funksionering, die ontwikkeling van 'n beter selfbeeld en positiewe agentskap. Verder kan humor individue bemagtig om negatiewe (bedreigende) situasies beter te hanteer (Pollak \& Freda, 1997; White, 2001; Abel, 2002; Kirsh \& Kuiper, 2003; Vilaythong et al., 2003).

Individue wat as mense met 'n bogemiddelde humorsin beskryf word, is minder neuroties (angstig) en sosiaal meer gemoedelik en aanvaarbaar (Cann \& Calhoun, 2001:126). Ruch (aangehaal in Lefcourt \& Martin, 1986) bevind in sy studie dat humorsin 'n persoonlike karaktertrek is en individue kan help om spanning of depressie te vermy, of bedreigende situasies beter te hanteer. Ook

2 Dit bied 'n moontlike verklaring waarom (aspirant-) onderwysers onbewustelik huiwerig is om humoristiese tekste te gebruik - die klassituasie kan dalk onhanteerbaar raak. 
Oberjohn (2002:24) se data dui daarop dat humorsin verband hou met sosiale vaardighede, soos gemeet aan portuuraanvaarding en vriendskappe.

Uit die refleksie van studente in die tersaaklike navorsingsprogram kom dit duidelik na vore dat die integrasie van humoristiese tekste beslis tot die skryf van parodieë bygedra het - 'n opdrag ("skryf 'n storie") wat dikwels in skoolverband deur leerders afgerammel of verwaarloos word. Ook die skryf van limerieke in pare of groepe van drie het die studente se houding ten opsigte van die skryfopdrag positief beïnvloed, veral omdat hulle soveel by mekaar geleer het en deur die entoesiasme en kreatiwiteit van ander in die groep geïnspireer is. ${ }^{3}$ Een student het spesifiek daarvan melding gemaak dat sy nog (soos) altyd angs ervaar het voordat sy 'n kreatiewe skryfopdrag moes uitvoer, maar in hierdie geval 'n nuwe opgewondenheid beleef het oor al die moontlikhede wat in die klas verken is. Nog iets wat heelwat studente opgemerk het, is die vryheid wat met die integrasie van humoristiese tekste gepaard gaan, en dat dit aan hulle kreatiewe energie gegee het.

\subsubsection{Kognitiewe styl, persoonlikheid en humor}

Alhoewel daar individuele persoonlikheidsverskille tussen onderwysstudente bestaan, meen Williams en Burden (1997:96) dat die verskille nie staties is nie. Konstruktivistiese leerteorieë konsentreer daarop om betekenisgewing en -konstruksie te sien as kennis wat oorganklik, voorlopig en relatief is. Hulle ag dit dus belangrik om op maniere te let waarop individue hulle wêreld en hulle persepsie van hulleself in die wêreld (meer spesifiek die leersituasie) beskou.

Om te sien hoe individuele leerstyle lyk, is dit nodig om 'n samevatting van Witkin (Griffiths \& Sheen, 1992) se konsepte van veldafhanklikheid teenoor veldonafhanklikheid (hierna VA/VO genoem) te maak. 4 Hierdie konsepte wat volgens Williams en Burden (1997:91) in die psigolinguistiek steeds as belangrik beskou word, is later onderskeidelik tot globale en analitiese leerstyle uitgebrei.

3 Hierdie koöperatiewe leergeleentheid het dus daartoe bygedra dat hulle meer grondige insae gekry het oor groepwerk as onderrigstrategie. Dit het hulle as aspirant-onderwysers toegerus om dit self later in die klaskamer toe te pas.

$4 \quad$ VA-mense word beskryf as sosiale mense, geïnteresseerd in mense, bereidwillig om ander te help, besorg oor ander, mense wat baie mense ken en ook deur baie geken word. Daarteenoor is VO-mense individualisties, afsydig en meer besorg oor idees en beginsels as oor mense (Jensen, 2000:140, 141). 
Alhoewel navorsers Witkin se VA/VO-hipoteses as kognitiewe style kan sien, het dit tog ook affektiewe implikasies. Navorsing wat deur Damasio (Arnold \& Brown, 1999:1) gedoen is, toon aan dat emosies deur neurobiologiese faktore bepaal word. Daar is wel 'n mate van ooreenkoms tussen Witkin se konsepte van VA/VO en latere kennis aangaande breinfunksionering, meer spesifiek ten opsigte van onderskeidelik die regter- en linkerhemisfeerspesialisering (Jensen, 2000:17), ekstro- en introversie (Arnold \& Brown, 1999:11) en individuele leerstyle.

Wat vir hierdie artikel oor die gebruik van humoristiese tekste in die taalonderrigsituasie van waarde is, is die navorsingsbevindings van Chapelle en Roberts (1986:43) wat aantoon dat VO-leerders meer geneig is om dubbelsinnigheid (ambiguity) te aanvaar. Hierdie leerders se groter buigsaamheid dui verder op hulle potensiaal tot kreatiwiteit. Chapelle en Roberts (1986:31) definieer vier soorte dubbelsinnige situasies in hierdie verband: nuwe situasies, komplekse situasies, onoplosbare situasies en ongestruktureerde situasies. Al vier hierdie soorte dubbelsinnigheid hou duidelik verband met inkongruensie as 'n humorelement (Van Niekerk, 2001:56) - dit verwys dus na die individu se vermoë om paradokse te hanteer en betekenis daarin te vind.

Lefcourt (2001:76) verwys na sy eie ondersoeke $(1974 ; 1982)$ wat aantoon dat humor in 'n sterker mate aangetref word by persone wat hulleself as aktief en selfhandhawend in hulle lewenservarings beskou, as by fatalistiese en passiewe persone. Hierdie bevindings het Lefcourt en sy kollegas die afleiding laat maak dat daar ' $n$ betekenisvolle verband tussen humor en die lokus van kontrole (beheer) is, en dat individue met 'n goeie humorsin meer daartoe geneig is om 'n aktiewe houding teenoor hulle ervarings te hê as diegene met ' $n$ minder goeie sin vir humor. ' $n$ Verdere afleiding is dat humor met meer aktiewe benaderings (pro-aktief/deelnemend) geassosieer word, eerder as met vermydende (reaktiewe) hanteringsmeganismes (Martin \& Lefcourt, 1983).

Lefcourt (2001:83) maak melding van McGhee (1979) se bevindings oor ouers se spelerige omgaan met kinders en bring dit in verband met 'n omgewing van veiligheid. McGhee koppel humorontwikkeling aan taaiheid (opgewassenheid), moeilike lewensomstandighede en portuurkonflik. Verder assosieer McGhee grapperigheid, lag, hansworsery (narrestreke) en ander vorme van humorinisiasie met fisieke en verbale aggressiwiteit. 
In verband met persoonlikheidseienskappe doen Clabby (1980:309) verslag van sy ondersoek waarin hy bevind het dat gevatheid (spitsvondigheid) die nouste verband hou met kreatiwiteit en persoonlike aanpasbaarheid. Ander ondersoeke dui daarop dat humoristiese persone beter selfbeeldpersepsies het, meer gewild is en ' $n$ meer opgeruimde en vriendelike temperament het, soos ook die geval met ekstroverte is (Kuiper et al., 1995; Wrench \& McCroskey, 2001).

Martin et al. (2003:49) stel voor dat 'n sin vir humor gekonseptualiseer kan word as 'n kognitiewe vermoë, 'n estetiese respons, 'n gewoontepatroon, 'n emosioneelverwante temperament, 'n houding en 'n hanteringstrategie of verdedigingsmeganisme. Die humorskaal wat hierdie outeurs ontwerp het, het 'n intra-/interpersoonlike kontinuum, sowel as 'n onskadelike/skadelike dimensie (Martin et al., 2003:51-52). 'n Ondersoek toon dat om humoristies of snaaks (funny) te wees, 'n persoon baie grappe moet kan genereer en die beste grappe moet kan identifiseer en kies (Dewitte \& Verguts, 2001:39). Laasgenoemde eienskap hou dus verband met 'n persoon se sensitiwiteit vir die sosiale omgewing. Dié ondersoek toon 'n ooreenkoms met soortgelyke vorige bevindings van Attardo en Raskin (1991).

Ten einde te bepaal wat elke individuele student se humorstyl is, is in die navorsingsprogram gebruik gemaak van Martin et al. (2003) se gestandaardiseerde humorstylvraelys, 5 wat deur net twaalf studente ingelewer is. Die humorstylvraelys toon die volgende resultate, en die punte van die onderwysstudente (genommer volgens hulle parodietekste) toon 'n verband met die persoonlikheidseienskappe wat in die eerste kolom genoem word, naamlik faktore wat selfopheffing, affiliasie, selfspot en aggressie meet.

5 Die Afrikaanse weergawe van die vraelys (Martin et al., 2003) word aan die einde van die artikel as bylae aangeheg. 
Tabel 1: Humorstyle van studente

\begin{tabular}{|c|c|c|c|c|c|c|c|c|c|c|c|c|c|}
\hline & \multicolumn{13}{|c|}{ Studentenommers volgens parodietekste } \\
\hline & 1 & 2 & 3 & 4 & 5 & 6 & 7 & 8 & 9 & 10 & 11 & 12 & 13 \\
\hline Humorstyl & \multicolumn{13}{|c|}{ Totale punt uit 56 vir elke styl } \\
\hline $\begin{array}{l}\text { Selfopheffing } \\
\text { - Humoristiese uitkyk } \\
\text { op die lewe } \\
\text { - Gebruik humor om } \\
\text { stres te hanteer } \\
\text { - Openheid vir nuwe } \\
\text { ervarings } \\
\text { - Positiewe selfbeeld }\end{array}$ & 33 & 44 & 41 & - & 38 & 28 & 38 & 38 & 24 & 39 & 35 & 31 & 30 \\
\hline $\begin{array}{l}\text { Affiliasie } \\
\text { - Sê snaakse dinge } \\
\text { oor self en ander } \\
\text { - Vertel grappe } \\
\text { - Gevatheid om ander } \\
\text { te amuseer } \\
\text { - Aanvaarding van } \\
\text { self en ander }\end{array}$ & 46 & 44 & 44 & - & 43 & 25 & 54 & 44 & 44 & 51 & 52 & 46 & 36 \\
\hline $\begin{array}{l}\text { Selfspot } \\
\text { - Sê snaakse goed ten } \\
\text { koste van self } \\
\text { - Lag saam met ander } \\
\text { oor self } \\
\text { - Selfverkleinerend } \\
\text { - Mate van lae } \\
\text { selfbeeld en } \\
\text { vermyding }\end{array}$ & 36 & 41 & 33 & - & 37 & 20 & 32 & 41 & 24 & 37 & 31 & 32 & 31 \\
\hline $\begin{array}{l}\text { Aggressie } \\
\text { - Vyandig teenoor } \\
\text { ander, manipulerend } \\
\text { - Afbrekend, } \\
\text { verkleinerend van } \\
\text { ander } \\
\text { - Terg ander, } \\
\text { sarkasme } \\
\text { - Seksistiese, } \\
\text { rassistiese humor }\end{array}$ & 20 & 39 & 32 & - & 24 & 18 & 22 & 31 & 10 & 27 & 24 & 36 & 23 \\
\hline $\begin{array}{l}\text { TOTAAL } \\
\text { Uit moontlike } 224\end{array}$ & 135 & 168 & 150 & - & 142 & 91 & 146 & 154 & 102 & 154 & 142 & 145 & 120 \\
\hline
\end{tabular}

'n Duidelike patroon kom uit die gegewens in die humorstylvraelys na vore, naamlik dat die meeste studente se affiliasiehumor die sterkste faktor in hulle styl is. Dit beteken dat hulle snaakse goed sê oor hulleself en ander, grappe vertel, gevat is met die doel om te amuseer, en dat hulle hulleself en ander aanvaar. Student no. 6 is 'n uitsondering: haar selfopheffing is die sterkste stylfaktor en dit be- 
teken dat haar humoristiese uitkyk op die lewe bogemiddeld is, dat sy humor gebruik om stres te hanteer, dat sy oop is vir nuwe ervarings en 'n positiewe selfbeeld het. Student no. 2 se profiel lyk ook anders, naamlik dat haar selfopheffing en affiliasie ewe sterk is.

Verder is die meeste studente se aggressiehumor die minste, en dit dui daarop dat hulle min vyandigheid en manipulasie in hulle humor openbaar, dat hulle nie afbrekend en verkleinerend is nie, dat hulle nie graag terg of sarkasme gebruik nie, en minder geneig is tot seksistiese of rassistiese humoruitings. Student no. 12 se selfopheffingshumor is die minste.

Nog 'n patroon wat uit die tabel blyk, is dat al die studente se humor meer geneig is om interpersoonlik (gerig op ander) as intrapersoonlik (gerig op self) te wees. Hulle gebruik humor dus meer om deel van die groep te wees en minder om hulleself op te vrolik of met hulleself te spot. Daar is wel vier studente wie se intrapersoonlike humorgebruik vergelykbaar hoog is, naamlik no. 2 en 3 (wie se selfopheffingstelling besonder hoog is), en no. 2 en 8 (wie se selfspottelling aansienlik hoër as die ander s'n is).

Vervolgens word gekonsentreer op gegewens wat uit die literatuurstudie oor angs en humor voortspruit.

\subsubsection{Angs en humor}

Die gebruik van humoristiese tekste kan tot die verligting van angs bydra. Individue met 'n humorsin kan beter kognitiewe waardebepalings maak van gebeure en situasies wat hulle ervaar (Kuiper et al., 1995:371). Navorsingsresultate toon dat humoristiese individue laer vlakke van waargenome spanning en depressie toon en minder geneig is om disfunksionele selfevaluerende standaarde te hê (Lefcourt, 2001:85, 87). Hoër humorvlakke kan ook geassosieer word met meer positiewe kognitiewe waarneming, sterker motivering en 'n positiewer affek om take te voltooi (Kirsh \& Kuiper, 2003:34).

Oxford (1999:62-63) is van mening dat taalangs, soos ander vorme van angs, gekenmerk word deur ondermynende gedagtes, gevoelens van vrees, 'n swak selfbeeld, 'n lae toleransie vir dubbelsinnigheid, 'n kleiner vermoë om risiko's te loop, vrees vir kompetisie en sosiale angstigheid, wat gevolglik tot swakker kommunikasievaardighede lei. Horwitz (aangehaal in Gardner \& Maclntyre, 1993:5) en Maclntyre (2002:66) beskryf taalangs as 'n komplekse ervaring wat gedeeltelik verband hou met kommunikasievrees, vrees vir sosiale evaluering en toetsangs. Hiervolgens is kommunikasievrees 'n 
respons op 'n werklike of verwagte praataksie (lees ook: kreatiewe skryfaksie). Dit is ook bekend dat formele leersituasies en eksamens tot groter angsvlakke aanleiding gee (Maclntyre, 2002:66). Die antitese van die angstige leerder is volgens Gardner en Maclntyre (1993:6) dié een met selfvertroue. Laasgenoemde navorsers meen dat selfvertroue gedefinieer kan word as 'n gebrek aan taalangs en 'n positiewe selfwaarde wat taalvaardigheid betref.

Bevindings van 'n ondersoek deur Abel (2002) bevestig dat humor angs kan verminder. Sy bespreek Lazarus en Folkman (Abel, 2002:366) se konsep van die kognitief-affektiewe skuif wat as gevolg van humor plaasvind, naamlik dat humor veroorsaak dat 'n persoon se omgang met potensieel bedreigende elemente in die omgewing (sogenaamde negatiewe situasies) meer buigsaam kan wees deurdat groter openheid en kreatiwiteit met betrekking tot stimuli ervaar word. Hierdie bevinding het veral implikasies vir eksamenspanning (Kuiper et al., 1995). Humor kan daartoe bydra dat die waarnemer 'n groter afstand van die bedreigende omstandighede kan verkry en dit beter kan hanteer - emosioneel kan die leerder hom-/haarself dus beter distansieer. Vilaythong et al. (2003:86) lewer navorsingsbewys dat humor spanning verminder deur hoop (positiewe verwagting of hoopvolle afwagting) te versterk.

'n Ondersoek deur Clapman (2001:339) bevestig dat angs kreatiewe denke inhibeer, 'n leerder se aandagsduur verkort en geheue en oordeel negatief beïnvloed - daarteenoor kan ontspanning en humor kreatiewe prestasie verbeter. Kuiper en Martin (Lefcourt, 2001: 107) ondersteun die bevinding dat humor en lag terapeutiese waarde met betrekking tot spanning en angs het (vgl. ook Freud, 1916). Humor kan dus 'n positiewe uitwerking in die klas hê wat angs betref. Terwyl daar mense is wat humor gebruik om hulle eie angs te verminder, kan aanstootlike humor egter ook angs (vrees vir aggressie/wrok/vergelding/uitsluiting) veroorsaak.

Ter wille van triangulasie om die data wat beskryf word, te verifieer, maar ook as onderriginstrument om die onderwysstudente professioneel voor te berei as reflektiewe opvoeders, is die studente in die navorsingsprogram voortdurend aan refleksievrae blootgestel wat hulle individueel moes beantwoord. Die vrae wat aan die begin van die onderrigprogram (in April 2004) ingesluit is, was onder andere (invulvrae sowel as spasie vir kommentaar):

- Reflekteer oor die week se aktiwiteite. 
- Maak melding van jou waarnemings van klasgebeure en interaksie, jou gevoelens en gedagtes daaroor, en jou interpretasie van die opvoedkundige waarde daarvan.

Toe gevind is dat die studente dit moeilik vind om die opdrag net so "oop" uit te voer, is hulle een week aan meer spesifieke vrae blootgestel om die proses te fasiliteer, byvoorbeeld:

- Kies en omkring drie woorde in 'n kolom gevoelswoorde (bv. opwindend, moeilik, lekker, vervelig, ontspanne, frustrasie, spanning, uitdaging, lewendig, interessant, nuuskierig) om jou ervaring van die limerieke-oefening te beskryf.

- Motiveer jou antwoord op die vorige vraag met voorbeelde uit jou ervaring van die lesgebeure.

- Hoe het jy die samewerking met 'n spanmaat ervaar? Kom jy agter dat dit vir jou beter/slegter is om saam met sekere mense te werk? Noem voorbeelde sonder om name te noem.

- In watter mate sal hierdie oefening jou onderrig van Afrikaans in die praktyk beïnvloed?

- Hoeveel beïnvloed jou persoonlike/akademiese/studentelewe jou ervaring van die lesse?

- Hoeveel beïnvloed die humormateriaal jou kreatiewe denke?

- Hoe sou jy die oefening(e) wysig as jy dit in jou eie onderrig gebruik?

Sake wat in die groepsrefleksie baie reaksie uitgelok het, was die ontdekking van die bruikbaarheid van pikturale humor en die kreatiewe skryfmoontlikhede van die limeriek en die parodie. Die studente het uitgebreid kommentaar gelewer oor die assessering van mekaar se werk en dit het veral na vore gekom dat hulle onvoorbereid voel om skryfwerk in die skool werklik objektief te assesseer. Dit het voorgekom asof die mondelinge onderhoudsgesprek vir die studente waardevol was, veral ten opsigte van die feit dat die gebruik van humoristiese tekste in 'n groter kulturele konteks en as deel van die hele onderrigprogram geplaas is. ' $n$ Groot deel van die gesprek het gehandel oor die skryfproses en hoe die gegewe stimuli daartoe bygedra het, asook wat die effek van groepwerk in pare op elkeen gehad het.

In die antwoorde op die gestruktureerde refleksievrae in die onderhoud het twee studente opgemerk dat hulle dalk in hulle eie onderrig 
by skole eerder met groepe van vier leerders sal werk om limerieke te laat skryf. Ander het egter gereageer dat daar dan te veel energie, individuele verskille en moontlikheid vir konflik is wat eers opgelos moet word voordat die kreatiewe "sap kan vloei". Dit was ook duidelik dat nie almal se humorsin ooreenkom nie en dat daar moontlik versoenbaarheidsprobleme in groepwerk kan ontstaan wat die kreatiewe proses kan inhibeer.

Tydens die groepsrefleksie in die navorsingsprogram het die studente melding gemaak van die waarde wat agtergrondinligting het (wat sou aansluit by die ontwikkeling van leerders se ensiklopediese kennis) om spotprente te interpreteer. Hulle het ook genoem dat die pikturale humor makliker herkenbaar is, omdat 'n mens dadelik die situasie deur middel van die visuele leidrade kan opsom. Daarby is hulle van mening dat die spotprent leerders moontlik kan stimuleer om die meegaande berig in die koerant te lees, wat andersins dalk nie sou gebeur nie.

\section{Bespreking}

Die formele taalonderrigbenaderings wat tot dusver voorrang geniet het (Blacquière, 1989; Botha, 1989), kon dalk daartoe bydra dat leerders se kreatiwiteit geïnhibeer is. Onderwyskundiges erken dat taalonderwysers in die verlede in 'n sterker mate georiënteer is ten opsigte van die beleidsdoelstellings en doelwitte van die Nasionale Kurrikulumverklaring, as wat hulle opgelei is om 'n teoretiese onderbou te konseptualiseer (Wes-Kaap Onderwysdepartement, 2006:4). Gevolglik was daar 'n gebrek aan klem op kwessies wat met epistemologie verband hou en wat die konseptuele gereedskap verskaf het. Dit het moontlik daartoe gelei dat, alhoewel taalonderwysers opgelei is om die bestaande reëls en strukture van 'n taal (formeel en inhoudelik) te ken, te beheers en tegnies (meganies) te assesseer, hulle nie noodwendig na vernuwing, kreatiewe (abstrakte en kritiese) denke en die ontwikkeling van hulle eie verbeelding gegroei het nie.

Faktore wat kreatiwiteit kan blokkeer, word deur Abdallah (1996) opgesom as 'n gebrek aan sekuriteit, 'n behoefte om te konformeer, 'n onvermoë om persepsies en evaluerings vrylik te gebruik, sowel as streng, rigiede beroepsoriëntering; perseptuele, kulturele en emosionele blokkasies; gewoonte en konformiteit; 'n gebrek aan die nodige inligting en kognitiewe onvermoë; ekstrinsieke motivering (Amabile, 1983); en reëls, regulasies, administratiewe voorskrifte en assesseringsdruk. 
Die outeurs is van mening dat genoemde blokkasies (vgl. Krashen se affektiewe filter) verminder kan word deur die gebruik van humoristiese tekste. Die onderhawige navorsingsprogram het juis aangetoon hoedanig humor onderwysstudente se kreatiewe skryfvermoë ontwikkel het (Kruger, 2007). Taalonderwysstudente kan dus intrinsiek tydens taalonderrig gemotiveer word deur ervaringsgerigte take met humoristiese tekste wat hulle kan stimuleer met die oog op aktiewe deelname aan hulle eie kreatiewe ontwikkeling. Sodanige taalonderrig behels dat leerders se emosies in die onderrigproses gerespekteer en gekanaliseer word. Die gebruik van humoristiese tekste kan 'n katalisator vir kreatiwiteit in taalonderrig wees.

Die opleiding van taalonderwysers behoort beskikbare inligting oor affektiewe onderwys in te sluit. Nuwe stemme in die opvoedkunde wat emosionele geletterdheid van leerders propageer, behoort egter krities kennis te neem van die moontlikhede van manipulasie en affektiewe inhibisies van leerders (en onderwysers) in die taalklaskamer. Ten spyte van die waardevolle bydrae wat die Affektiewe Onderwysbeweging tot die verruiming van sowel onderrigstrategieë as die leerervaring en -inhoude in die onderwys gemaak het, is dit volgens Legutke en Thomas (1991:48-69) duidelik dat affektiewe onderrig fundamenteel intervensionisties is - dit berus op ingryping en bemiddeling en is nie as sodanig teoreties gefundeer nie.

Die kwasi-terapeutiese rol van die onderwyser in affektiewe (lees: responsiewe) onderwys hou die negatiewe moontlikheid in dat die leerders hulle outonomie kan verloor, pionne in 'n opvoedkundige spel kan word en gevoelens van manipulasie of vervreemding kan ervaar. Ook die bevindings aangaande humor en angs het implikasies vir die taalonderrigsituasie. Die gevaar bestaan dus dat die integrasie van gevoelens (en humor) in manipulerende instrumente kan ontaard. In hierdie verband noem Legutke en Thomas (1991:4869) enkele (geldige) kriteria waarmee sogenaamde affektiewe of humanistiese onderrigtegnieke met die oog op die integrasie daarvan in taalonderrig geëvalueer kan word:

- Die konteks en onderwerp behoort pedagogies en metodologies sistematies en tematies geïntegreer te word, sodat dit nie ruimte skep vir twyfelagtige en willekeurige selfervaringsgeleenthede nie. Andersins kan dit lei tot die vervreemding van sensitiewe leerders en dus teenproduktief wees. Verder behoort die bewuswording van kognitiewe prosesse en sensoriese waarnemings met mekaar in verband gebring te word, en met kritiese refleksie gepaard te gaan. Alhoewel die konsep van bewuswording waardevol is in leerders se emosionele en sosiale ontwikkeling, moet 
die rol van die kommunikatiewe taak hierdie bewuswording fasiliteer deur op sowel relevante onderwerpe as op die emosionele en linguistiese inhoud te fokus.

- Die mate waarin leerders reeds voorheen aan hierdie soort kommunikatiewe take blootgestel is, asook die opleiding en sensitiwiteit van onderwysers om ervaringsleer en refleksie te hanteer, behoort in ag geneem te word. Die rede hiervoor is dat die mate van selfopenbaring en sosiale mobiliteit in die klaskamer op sigself vir deelnemers bedreigend kan wees en tot inhiberende angs (as gevolg van pynlike emosies en moontlike groepsdruk) kan lei.

- Die aard van die kommunikatiewe take kan wel tot verhoogde motivering by studente en skoolleerders lei, omdat hulle daaraan wil deelneem. Almal wil graag meer van hulself leer. Tog behoort die onderwyser dit nie buite rekening te laat dat leerders hulle dalk moontlik teen deelname kan verset nie - as gevolg van 'n gebrek aan sekuriteit en vertroue, of weens angs, verleentheid of ' $n$ inherente behoefte om teen inmenging beskerm te word.

- Alhoewel kommunikatiewe (funksionele) taalgebruik aan leerders geleenthede bied om aan hulle eie persoonlike waardes en ervaringswerklikhede uitdrukking te gee, is die taalfunksies wat daarmee gepaard gaan moeilik sistematies voorspelbaar en meetbaar en kan dus maklik afgeskeep word. Gevolglik moet onderwysers nie slegs goed daarin onderlê wees om te kan onderskei watter vlakke van assesseringstandaarde en vereistes deur kommunikatiewe take aan leerders gestel word nie. Onderwysers behoort ook doelgerigte en doeltreffende hulpbronne (handboeke, leermateriaal) beskikbaar te hê om die taalaspekte te onderrig soos die konteks van die leerinhoud dit moontlik maak.

- Die verband tussen kommunikatiewe take en die groter geheel van die onderrig- en leerproses behoort onderskei en met omsigtigheid hanteer te word. 'n Onderwyser moet dus besef hoe 'n aktiwiteit sowel kwalitatief as kwantitatief in die proses hoort (as inleiding, vaslegging, toepassing of retrospeksie en refleksie) en in watter mate dit summatief en/of formatief assesseerbaar is.

Indien die gebruik van humoristiese tekste in taalonderrig 'n sentrale deel van taalonderrigprogramme uitmaak, is dit noodsaaklik om te begryp watter teoretiese beginsels sodanige onderrigpraktyk onderlê. Die kommunikatiewe benadering tot taalonderrig (Blacquière, 1989; Arnold \& Brown, 1999; Van den Berg, 2004) is geskik vir die 
gebruik van humoristiese tekste in huistaal- sowel as addisionele taalonderrig (Botha, 1989; Van den Branden, 1996). Soos die kommunikatiewe benadering, pas die taakgerigte benadering goed by die konstruktivistiese leerteorieë en die humanistiese (responsiewe) taalonderrigbenadering, omdat dit leerdergesentreerd is en dus op die leerder se behoeftes konsentreer (Clark, 1996:252; Van den Branden, 2000:13).

Olalla (2004) se perspektief dat die daaglikse gebruik van taal ten alle tye gepaardgaan met die ervaring van sekere emosies, noodsaak dat onderwysers herbesin oor leerders se interaksie met tekste tydens taalonderrig. Die moontlikheid moet oorweeg word dat daar nie slegs gepraat word van leerders se denke, gesprekke of interaksies nie, maar dat hulle emosies ook tydens hulle ervarings met tekste in berekening gebring moet word - leer deur ervaring word dus in die wydste sin beklemtoon. Die leerder se begrip en ervaring van die teks spruit juis uit 'n spesifieke emosionele ruimte, wat bepalend sal wees vir die leerder se reaksies tot die teks en ook tot ander leerders se response tot dieselfde teks. Dit is duidelik dat die gebruik van taal in humoristiese tekste, sowel as die taalgebruik van die leerders in interaksie met daardie tekste, 'n aanduiding sal wees van leerders se emosionele intelligensie, met ander woorde die vermoë van die leerders om hulle emosies te identifiseer, te erken en effektief in die proses van leer te bestuur.

Die filosoof Robert Solomon (1993) se uitgangspunt is dat die kind se emosies nie slegs gesien moet word as emosionele uitbarstings of instinktiewe reaksies nie, maar as intelligente en sterk konseptuele interaksies met die leefwêreld en skoolkontekste. Hierdie uitgangspunt steun die outeurs se mening dat nuwe geleenthede om kreatief oor leerders se emosionele ingesteldheid te dink, dringend noodsaaklik is. Die konsep van emosionele intelligensie wat deur Goleman (1996) bekendheid verwerf het, word as verdere boublokke vir filosofiese perspektiewe oor emosionele ontwikkeling aanvaar.

Wat vir die integrasie van humoristiese tekste in emosionele geletterdheid en taalonderrig relevant is, is die skakels wat Van den Branden (2000) en Cook (2000) tussen taakgerigte taalonderrig, kreatiwiteit en taalspel lê. Veral Cook (2000:150) beklemtoon dit dat taalspel sosiaal sowel as kognitief belangrik geag word en dat die speel met woorde, grense ${ }^{6}$ en betekenis nie net ' $n$ middel is omdat

6 Hier word spesifiek verwys na (ongeskrewe) sosiale norme en reëls, konvensies. 
dit na leerders se behoeftes omsien nie, maar ook as 'n doel gesien kan word. Die vermoë om assosiasies tussen verskynsels te maak en die ontspanning van 'n mens se identiteitsgrense hou verband met die proses waardeur inhibisie en konstruktiewe regressie 7 plaasvind (Ehrman, 1999:78). In die geval van taalspel (humorwaardering en -ekspressie) as 'n omkering van grense, is dit dus moontlik dat affektiewe faktore as katalisator vir kreatiwiteit gebruik kan word.

'n Besonder bruikbare stylfiguur en gediggenre waaroor meer navorsing gedoen kan word en wat met goeie gevolg in affektiewe taalonderrig gebruik kan word, is die limeriek (vgl. Baring-Gould, 1968; Harrowven, 1976; Cuijpers, 1988; De Vos, 2000). Die refleksie van die studente het die belang van die limeriek as oefening vir satire duidelik na vore gebring. Verder was dit 'n bruikbare aktiwiteit om studente bewus te maak van klankmanipulasie soos rym en ritme, en hulle te laat soek na sinonieme deur middel van assosiasies wat deur die pikturale humor gestimuleer is. Die oefening het ook met pret gepaard gegaan en dit het nie vir die studente gevoel asof hulle besig was om te leer nie (Nilsen \& Nilsen, 1999; Apol, 2002; Dickson, 2002).

Nietemin sal dit goed wees om in so 'n onderrigprogram meer geleentheid te skep vir terugvoer en die beluistering van mekaar se limerieke. Gediggies wat nie presies in die limeriekpatroon pas nie, kan beskou word as speelse versies - ook 'n aanvaarde digvorm waarmee leerders kan eksperimenteer sonder die gewone bedreiging wat met kreatiewe skryftake gepaard gaan (De Vos, 2000). Dit was ook opmerklik dat heelwat studente melding gemaak het van hoedanig hulle van mekaar verskil, en dat nie almal maklik aan hierdie opdrag kan saamwerk nie.

By een hoërskool waar 'n onderwysstudent haar skoolbesoek afgelê het, bestaan daar 'n bundel met limerieke wat leerders oor onderwysers in die skool geskryf het. Studente het selfs die moontlikheid genoem dat 'n nasionale limeriekkompetisie gehou word. Sulke groter projekte kan aangepak word om leerders se woordgevoeligheid en algemene taalsensitiwiteit te ontwikkel en die Afrikaanse kultuurskat uit te brei. Op hierdie manier kan leerders aangemoedig word om kultuurskeppers te wees. Vergelyk byvoorbeeld die

7 'n Persoon se (onbewuste) verplasing na vroeë kinderjare (die oproep van herinneringe) deur middel van spel. 
geslaagde kompetisie wat die British Culture Association onlangs georganiseer het om die affektiewe in taalonderrig met limerieke te verryk, waarvan die resultate daarop dui dat "[s]tudents used wit, empathy and humour to express their views and came up with interesting, personal observations about mobiles, robots, e-mail, snail mail, teachers, technology, and being tangled in the world wide web" (Anon., 2008).

' $n$ Ander aspek wat verdien om verder bestudeer te word, is die wyse waarop die gebruik van humormateriaal kan bydra tot die oplossing van dissiplineprobleme in die klaskamer. Hierdie studie toon aan dat die gebruik van humormateriaal positiewe gebruiksmoontlikhede kan hê, juis omdat dit leerders toelaat om met taal te speel en enige vorm van opstandigheid kreatief kanaliseer. Dit is egter ook moontlik dat onderwysers of leerders se humorwaardering en ekspressie aanstootlik vir die ontvangers daarvan kan wees, of dat die verstaan in die resepsie daarvan nie plaasvind nie en die ontvangers of deelnemers geïntimideer of uitgesluit voel. Die gevare wat aan die gebruik van humormateriaal verbonde is, is in hierdie studie nie volledig verken nie.

Ook die ontwikkeling van kreatiewe skryfwerk as produk van taalonderrig met humormateriaal verdien meer aandag. Benewens die moontlikhede vir kreatiewe ekspressie, veronderstel die prosesbenadering wat gevolg is dat die onderriggewer die kreatiewe proses verstaan, en dat voldoende tyd daarvoor in die onderrigprogram ingeruim word. Oor hierdie aspek kan meer navorsing gedoen word, alhoewel dit moeilik is om kreatiwiteit te meet en te assesseer.

Alhoewel daar in die studie sprake is van kontekstuele faktore soos die onderwysbeleid, kultuurmanifestasies en adolessente as deel van 'n verbruikersamelewing, is krities-opvoedkundige perspektiewe nie toereikend aangeraak nie. In opvolgstudies kan meer navorsing oor die integrasie van humoristiese tekste in kulturele kontekste onderneem word en ook of dit taalonderwysstudente of onderriggewers kan bemagtig om diversiteit en inklusiwiteit in die taalklaskamer te bevorder. Alhoewel die studie herhaalbaar is, meen die outeurs dat daar kulturele faktore in die navorsingsprogram na vore kom wat nadere bestudering benodig. Dit geld veral vir die verband tussen vroulike en manlike humorvoorkeure - juis omdat so 'n groot deel van die onderwyserskorps uit vroulike persone bestaan, terwyl die leerders in die skole dogters sowel as seuns insluit. Humoristiese tekste sou dus ook in verdere studies gebruik kan word om 'n kritiese taalbewustheid in Afrikaans as huistaal sowel as addisionele 
taal te ontwikkel, om tekstuele linguistiek te bevorder, sowel as om die kulturele aspekte van humor as sosiolinguistiese verskynsel te bestudeer.

\section{Slotopmerkings}

Die outeurs wil hulle skaar by die mening van Heidegger (Sieler, 2005:108) wat beklemtoon dat die mens as wese nooit sonder emosie funksioneer nie en dat die mens se emosionele ingesteldheid uiteindelik sal bepaal hoe hy sy leefwêreld sal waarneem, dit sal interpreteer, daarop sal reageer en tot spesifieke aksie sal oorgaan. Hierdie sienswyse bied stof tot nadenke vir taalonderrig en noodsaak verdere navorsing.

Om leerders intrinsiek te motiveer, is dit volgens die outeurs belangrik om op hulle unieke en individuele belangstellings, behoeftes, aanlegte, persoonlikhede en leerstyle te konsentreer, en om hulle op 'n holistiese en responsiewe wyse te onderrig. In hierdie artikel is aandag gegee aan holistiese onderrigstrategieë met behulp van humoristiese tekste waarmee daar in 'n navorsingsprogram gepoog is om akademiese, sosiale en emosionele leergeleenthede te skep. Hierdie leergeleenthede sou die deelnemers in staat stel om interaktief deel te neem en verantwoordelikheid vir die eie leer te aanvaar.

Die outeurs het aangetoon hoedat die integrasie van humoristiese tekste in taalonderrig bygedra het tot die ontwikkeling van onderwysstudente se emosionele geletterdheid. Die effek van humor op die affektiewe het aandag geniet en emosionele geletterdheid as begrip is bespreek. Besondere klem is verder gelê op die verband tussen humor en die studente se belewenis van houding (gesindheid en motivering), kognitiewe styl en persoonlikheid, sowel as op humor en angs. Daar is spesifiek verwys na die resultate van 'n navorsingsprogram waarin die studente se humorstyle asook hulle refleksies oor die tersaaklike onderrigprogram met humoristiese tekste verwerk is.

\section{Geraadpleegde bronne}

ABDALLAH, A. 1996. Foster creativity in student teachers. Community review, 14:52-28.

ABEL, M.H. 2002. Humor, stress, and coping strategies. Humor, 15(4):365-381. AMABILE, T.M. 1983. The social psychology of creativity. New York: Springer. 
ANON. 2008. Learning language with limericks. Times of Malta: 13 Jul. http://www.timesofmalta.com/articles/view/20080713/education/learninglanguage-with-limericks Date of access: 17 Jul. 2008.

AOKI, N. 1999. Affect and the role of teachers in the development of learner autonomy. (In Arnold, J., ed. Affect in language learning. Cambridge: Cambridge University Press. p. 142-154.)

APOL, L. 2002. What do we do if we don't do haiku? Seven suggestions for writers and teachers. English journal, 91(3):89-97.

ARNOLD, J. \& BROWN, H.D. 1999. Introduction: a map of the terrain. (In Arnold, J., ed. Affect in language learning. Cambridge: Cambridge University Press. p. 1-24.)

ATTARDO, S. \& RASKIN, V. 1991. Script theory revis(it)ed: joke similarity and joke representation model. Humor, 4(4):293-347.

BABBIE, E. \& MOUTON, J. 2001. The practice of social research. New York: Oxford University Press.

BARING-GOULD, W.S. 1968. The lure of the limerick. London: Granada.

BARNARD, A. \& HERBST, R. 2005. The relationship between emotional intelligence and self-actualisation. South African journal of labour relations, 5371, Autumn.

BERK, R.A. 1998. Professors are from Mars, students are from snickers: how to write and deliver humor in the classroom and in professional presentations. Wisconsin: Mendota.

BLACQUIĖRE, A. 1989. Kommunikatiewe taalonderrig: moontlikhede vir Afrikaans tweede taal. Klasgids, 50-57, Mei.

BODENSTEIN, R. 1998. Language teaching in the light of neurological evidence. Journal for language teaching, 32(4):273-290.

BOLING, C.J. \& SENOKOSSOFF, G.W. 2007. Responsive teaching: Florida literacy and reading excellence professional paper. http://flare.ucf.edu Date of access: 25 Jun. 2008.

BOOYSE, C. 1992. Onderrigstrategieë ter verbetering van die houding van leerlinge teenoor Afrikaans as skoolvak. Potchefstroom: $\mathrm{PU}$ vir $\mathrm{CHO}$. (M.Ed.-tesis.)

BOTHA, L. 1989. Tweedetaalteorie vir die eerstetaalonderwyser. Per linguam, $5(1): 50-58$.

BRYANT, J., COMISKY, P. \& ZILLMANN, D. 1979. Teachers' humor in the college classroom. Communication education, 28(2):110-118.

CAINE, R.N. \& CAINE, G. 1991. Making connections: teaching and the human brain. Virginia: Association for Supervision and Curriculum Development.

CANN, A. \& CALHOUN, L.G. 2001. Perceived personality associations with differences in sense of humor: stereotypes of hypothetical others with high or low senses of humor. Humor, 14(2):117-130.

CHAPELLE, C. \& ROBERTS, C. 1986. Ambiguity tolerance and field independence as predictors of proficiency in English as a second language. Language learning, 36(2):27-45.

CHIASSON, P.E. 2002. Using humour in the second language classroom. The internet TESL journal, 8(3). http://iteslj.org Date of access: 4 Nov. 2003.

CLABBY, J.F. 1980. The wit: a personality analysis. Journal of personality assessment, 44(3):307-310.

CLAPMAN, M.M. 2001. The effects of affect manipulation and information exposure on divergent thinking. Creativity research journal, $13(3$ \& 4):335350. 
CLARK, J.L. 1996. Task-based learning: purposes, processes and everimproving knowledge and language. Journal for language teaching, 30(4):251-269.

COOK, G. 2000. Language play, language learning. Oxford: Oxford University Press.

CROOKES, G. 1992. Theory format and SLA theory. Studies in second language acquisition, 14:425-449.

CUIJPERS, P. 1988. Er was eens een boer in Timboektoe: de limerick als pleziervers. Amsterdam: Van Leeuwen.

DE VOS, P. 2000. So skryf jy 'n limerick. http://www.storiewerf.co.za Datum van gebruik: 9 Mar. 2003.

DE WIT, H.B. 2002. Emosionele intelligensie: 'n oorsig oor die konseptualisering en meting daarvan. Stellenbosch: Universiteit Stellenbosch. (M.A.-tesis.)

DENSCOMBE, M. 1998. The good research guide for small-scale social research projects. Philadelphia: Open University Press.

DENZIN, N.K. \& LINCOLN, Y.S., eds. 2005. The SAGE handbook of qualitative research. 3rd ed. London: Sage.

DEPARTEMENT VAN ONDERWYS kyk SUID-AFRIKA. Departement van Onderwys

DEWITTE, S. \& VERGUTS, T. 2001. Being funny: a selectionist account of humor production. Humor, 14(1):37-53.

DICKSON, R. 2002. Creating joy: adolescents writing poetry with young children. Voices from the middle, 10(2):384-392.

DREYER, J.A.E. 2005. 'n Opleidingsprogram in alternatiewe interaksiemetodes vir onderwysers. Pretoria: Universiteit van Suid-Afrika. (D.Ed.-proefskrif.)

EHRMAN, M. 1999. Ego boundaries and tolerance of ambiguity in second language learning. (In Arnold, J., ed. Affect in language learning. Cambridge: Cambridge University Press. p. 68-86.)

ENGELBRECHT, M.M. 1990. Selected techniques for reducing the affective filter in the English second language classroom. Stellenbosch: Stellenbosch University. (M.Ed. thesis.)

FARLEY, J. 1981. Perceiving the student: enriching the social studies through the affective domain. Theory into practice, 20(3):180-186.

FREHEIT, S.R. \& OVERHOLZER, J.C. 1998. The association between humor and depression in adolescent psychiatric inpatients and high school students. Journal of adolescent research, 13(1):32-49.

FREUD, S. 1916. Jokes and their relation to the unconscious. New York: Penguin.

GARDNER, H. 1991. The unschooled mind. London: Fontana.

GARDNER, R. 1985. Social psychology and second language learning: the role of attitudes and motivation. London: Arnold.

GARDNER, R.C. \& MACINTYRE, P.D. 1993. A student's contribution to second language learning. Part 2: Affective variables. Language teaching, 26:111.

GAY, G. 2000. Culturally responsive teaching: theory, research, and practice. New York: Teachers College Press.

GOLEMAN, D. 1996. Emotional intelligence: why it can matter more than IQ. London: Bloomsbury.

GOLEMAN, D. 1998. Working with emotional intelligence. London: Bloomsbury. 
GRACZYK, P.A., WEISSBERG, R.P., PAYTON, J.E., ELIAS, M.J., GREENBERG, M.T. \& ZINS, J.E. 2000. Criteria for evaluating the quality of school-based social and emotional learning programs. (In Bar-on, R. \& Parker, J.D.A., eds. The handbook of emotional intelligence: theory, development, assessment and application at home, school, and in the workplace. San Francisco: Jossey-Bass. p. 391-410.)

GRIFFITHS, R. \& SHEEN, R. 1992. Disembedded figures in the landscape: a reappraisal of L2 research in field dependence/independence. Applied linguistics, 13(2):133-148.

HARROWVEN, J. 1976. The limerick makers. London: Futch.

HUGO, A.J. 2001. Lees en studeer op tersiêre vlak: die affektiewe komponent van lees verdien ook aandag. Tydskrif vir taalonderrig, 35(2 \& 3):138-145.

JENSEN, E. 2000. Brain-based learning. San Diego: The Brain Store.

KHER, N., MOLSTAD, S. \& DONAHUE, R. 1999. Using humor in the college classroom to enhance teaching effectiveness in "dread courses". College student journal, 33(3):400-406.

KIRSH, G.A. \& KUIPER, N.A. 2003. Positive and negative aspects of sense of humor: associations with the constructs of individualism and relatedness. Humor, 16(1):33-62.

KRASHEN, S.D. 1985. The input hypothesis: issues and implications. London: Longman.

KRUGER, E. 2007. Die gebruik van humor om kreatiewe skryf in die onderrig van Afrikaans te stimuleer: 'n gevallestudie. Literator, 28(2):21-47.

KUIPER, N.A., MCKENZIE, S.D. \& BELANGER, K.A. 1995. Cognitive appraisals and individual differences in sense of humor: motivational and affective implications. Personality and individual differences, 19(3):359372.

LATHER, P. 1986. Issues of validity in openly ideological research: between a rock and a soft place. Interchange, 17(4):63-84.

LEFCOURT, H.M. 2001. Humor: the psychology of living buoyantly. London: Kluwer Academic Publishers.

LEFCOURT, H.M. \& MARTIN, R. 1986. Humor and life stress: antidote to adversity. New York: Springer.

LEGUTKE, M. \& THOMAS, H. 1991. Process and experience in the language classroom. London: Longman.

LESH, R., DOERR, H.M., CARMONA, G. \& HJALMARSON, M. 2003. Beyond constructivism. Mathematical thinking and learning, 5(2 \& 3):211-233.

LYTTLE, J. 2001. The effectiveness of humor in persuasion: the case of business ethics training. Journal of general psychology, 128(2):206-216.

MACINTYRE, P.D. 2002. Motivation, anxiety and emotion in second language acquisition. (In Robinson, P., ed. Individual differences and instructed language learning. Philadelphia: Benjamins. p. 45-68.)

MARTIN, R.A. \& LEFCOURT, H.M. 1983. Sense of humor as a moderator of the relation between stressors and moods. Journal of personality and social psychology, 45:1313-1324.

MARTIN, R.A., PUHLIK-DORIS, P., LARSEN, G., GRAY, J. \& WEIR. K. 2003. Individual differences in uses of humor and their relation to psychological well-being: development of the humor styles questionnaire. Journal of research in personality, 37:48-75.

MAYER, J.D. \& SALOVEY, P. 1993. The intelligence of emotional intelligence. Journal of intelligence, 17:433-442. 
McGHEE, P.E. 1979. Humor: its origin and development. San Francisco: Freeman.

McLAUGHLIN, B. 1987. Theories of second-language learning. London: Arnold.

MILES, M.B. \& HUBERMAN, A.M. 1994. Qualitative data analysis: an expanded sourcebook. London: Sage.

MULLIGAN, J. 1993. Activating internal processes in experiential learning. (In Boud, D., Cohe, R. \& Walker, D., eds. Using experience for learning. Buckingham: Open University Press. p. 46-58.)

NILSEN, A.P. \& NILSEN, D.L.F. 1999. The straw man meets his match: six arguments for studying humor in English classes. English journal, 88(4):34-42.

OBERJOHN, K. 2002. The funny papers: an examination of children's sense of humor, peer acceptance, and friendships. Cincinatti: Cincinatti University. (M.A. thesis.)

OLALLA, J. 2004. Emotions in learning and coaching: essays on the crisis in contemporary learning. Referaat gelewer by 9de jaarlikse kongres van International Coaching Federation, Boulders, USA. http://www. newfieldnetwork.com Date of access: 21 Jul. 2008.

OLIVIER, M.A.J. 2005. How do academics handle their job-related stress? South African journal of higher education, 19(2):345-358.

OXFORD, R.L. 1997. Constructivism: shape-shifting, substance and teacher education applications. Peabody journal of education, 72(1):35-66.

OXFORD, R.L. 1999. Anxiety and the language learner: new insights. (In Arnold, J., ed. Affect in language learning. Cambridge: Cambridge University Press. p. 58-67.)

PARK, J. 1999. Emotional literacy: education for meaning. International journal of children's spirituality, 4(1):19-28.

PIENAAR, A. 2004. Die verband tussen kognitiewe buigsaamheid en humorsin by adolessente. Bloemfontein: Universiteit van die Vrystaat. (M.Sc.-tesis.)

POLLAK, J.P. \& FREDA, P.D. 1997. Humor, learning, and socialization in the middle level classrooms. Clearing house, 70(4):176-178.

POPLIN, M.S. 1988. Holistic/constructivist principles of the teaching/learning process: implications for the field of learning disabilities. Journal of learning disabilities, 21(7):401-416.

RASMUSSEN, J. 2001. The importance of communication in teaching: a systems-theory approach to the scaffolding metaphor. Journal of curriculum studies, 33(5):569-582.

ROBERTS, J.W. 2002. Beyond learning by doing: the brain compatible approach. The journal of experiential education, 25(2):281-285.

SCHARLE, A. \& SZABÓ, A. 2000. Learner autonomy: a guide to developing learner responsibility. Cambridge: Cambridge University Press.

SHEPARD, R., FASKO, D. \& OSBORNE, F.H. 1999. Intrapersonal intelligence: affective factors in thinking. Education, 119(4):633-642.

SIELER, A. 2005. Coaching to the human soul: ontological coaching and deep change. Victoria: Newfield.

SOLOMON, R. 1993. The passions: emotions and the meaning of life. Indianapolis: Hackett.

STEVICK, E.W. 1999. Affect in learning and memory: from alchemy to chemistry. (In Arnold, J., ed. Affect in language learning. Cambridge: University Press. p. 43-57.) 
SUID-AFRIKA. Departement van Onderwys. 2002. Hersiene Nasionale Kurrikulumverklaring Grade R-9 (skole). Kaapstad: Departement van Onderwys.

SUID-AFRIKA. Departement van Onderwys. 2003. Nasionale Kurrikulumverklaring Grade 10-12 (skole). Kaapstad: Departement van Onderwys.

TOMLINSON, C.A. \& EIDSON, C.C. 2003. Differentiation in practice: a resource guide for differentiating curriculum, Grades 5-9. Alexandria: Association for Supervision and Curriculum Development.

TOROK, S.E., MCMORRIS, R. \& LIN, W.C. 2004. Is humor an appreciated teaching tool? Perceptions of professors' teaching style and use of humor. College teaching, 52(1):14-20.

ULLOTH, J.K. 2003. Guidelines for developing and implementing humor in nursing classrooms. Journal of nursing education, 42(1):35-37.

UNDERHILL, A. 1997. The psychological atmosphere we create in our classrooms. The language teacher online. http://langue.hyper.chubu. ac.jp Date of access: 5 Nov. 2003.

VAN DEN BERG, G. 2004. Die geleenthede wat uitkomsgebaseerde taalhandboeke bied vir die ontwikkeling van leerders se meervoudige intelligensies. Pretoria: Universiteit van Suid-Afrika. (D.Ed.-proefskrif.)

VAN DEN BRANDEN, K. 1996. Taakgericht onderwijs: de puntjes op de i. Taaluniversum Conferentiebundel. Het schoolvak Nederlands: verslag van de negende conferentie. Utrecht: Algemeen Publicatie Secretariaat. http://taalunieversum.org/ondewijs/conferentie_het_schoolvak_nederland Datum van gebruik: 22 Mar. 2009.

VAN DEN BRANDEN, K. 2000. Zeven vragen over taakgericht onderwys (en een poging tot antwoord erop ...). Vonk, 29(3):3-19.

VAN NIEKERK, J.E. 2001. Humor in kinderverhale: 'n vergelyking tussen geselekteerde Afrikaanse en Nederlandse tekste. Potchefstroom: PU vir CHO. (M.A.-tesis.)

VILAYTHONG, A.P., ARNAU, R.C., ROSEN, D.H. \& MASCARO, N. 2003. Humor and hope: can humor increase hope? Humor, 16(1):79-89.

WES-KAAP ONDERWYSDEPARTEMENT. 2006. WKOD Geletterdheid- en syferkundigheidstrategie 2006-2016. Kaapstad: Wes-Kaapse Provinsiale Regering.

WHITE, G.W. 2001. Teachers' report of how they used humor with students perceived use of such humor. Education, 122(2):337-347.

WILLIAMS, M. \& BURDEN, R.L. 1997. Psychology for language teachers. Cambridge: Cambridge University Press.

WRENCH, J.S. \& MCCROSKEY, J.C. 2001. A temperamental understanding of humor commmunication and exhiliratability. Communication quarterly, 49(2):142-159. Www.uni-duesseldorf.de/WWW/MathNat/Ruch/Texte/ TrentoRuch.pdf Date of access: 15 Sept. 2005.

WYCOFF, E.B. \& PRYOR, B. 2003. Cognitive processing, creativity, apprehension and the humorous personality. North American journal of psychology, 5:31-44.

ZINS, J.W., BLOODWORTH, M.R., WESSIBERG, R.P. \& WALBERG, H.J. 2004. The scientific base linking social and emotional learning to school success. (In Zins, J.E., ed. Building academic success on social and emotional learning: what does the research say? New York: Teachers College Press. p. 3-22.)

ZIV, A. 1984. Personality and sense of humor. New York: Springer. 
ZIV, A. 1988. The effect of humor on aggression catharsis in the classroom. The Journal of psychology, 121(4):359-364.

\section{Kernbegrippe:}

affektiewe onderwys

angs

emosionele geletterdheid

houding

humoristiese tekste

motivering

taalonderrig

Key concepts:

affective education

anxiety

attitude

emotional literacy

humorous material

language teaching

motivation 


\section{Bylae}

\section{Humorstylvraelys (Martin et al., 2003)}

[For further information please contact: Dr. Rod A. Martin, Department of Psychology, University of Western Ontario, London, Ontario, Canada N6A 5C2. Email: ramartin@uwo.ca.]

Mense beleef en druk humor op baie verskillende maniere uit. Hieronder volg 'n lys stellings wat verskillende maniere beskryf waarop humor beleef kan word.

Lees elke stelling asseblief versigtig deur en dui die mate aan waarin jy daarmee saamstem of nie saamstem nie. Reageer asseblief so eerlik en objektief as wat jy kan. Gebruik die volgende skaal:

\begin{tabular}{|c|l|l|l|l|l|l|}
\hline $\begin{array}{l}\text { Stem glad } \\
\text { nie saam } \\
\text { nie }\end{array}$ & $\begin{array}{l}\text { Stem } \\
\text { grootliks } \\
\text { nie saam } \\
\text { nie }\end{array}$ & $\begin{array}{l}\text { Stem } \\
\text { gedeeltelik } \\
\text { nie saam nie }\end{array}$ & $\begin{array}{l}\text { Stem } \\
\text { nóg } \\
\text { saam } \\
\text { nóg nie } \\
\text { saam nie }\end{array}$ & $\begin{array}{l}\text { Stem } \\
\text { gedeel- } \\
\text { telik } \\
\text { saam }\end{array}$ & $\begin{array}{l}\text { Stem } \\
\text { grotendeels } \\
\text { saam }\end{array}$ & $\begin{array}{l}\text { Stem } \\
\text { heeltemal } \\
\text { saam }\end{array}$ \\
\hline 1 & 2 & 3 & 4 & 5 & 6 & 7 \\
\hline
\end{tabular}

1. Ek is nie iemand wat grappies vertel en pret maak saam met ander mense nie

2. As ek depressief voel, kan ek myself met humor opvrolik.

3. Ek gebruik dikwels die foute wat ander maak om hulle te terg.

4. Ek laat mense te veel toe om vir my te lag en my te terg.

5. Dis vir my maklik om ander te laat lag.

Dit lyk of ek van nature humoristies van aard is.

6. Selfs in my eie geselskap verkneukel ek my oor die absurditeite van die lewe. 
7. Mense neem nie aanstoot aan die grappies wat ek maak nie.

$\begin{array}{lllllll}1 & 2 & 3 & 4 & 5 & 6 & 7\end{array}$

8. Ek sal maklik met myself spot as dit my familie en vriende laat lag.

$\begin{array}{lllllll}1 & 2 & 3 & 4 & 5 & 6 & 7\end{array}$

9. Mense lag nie maklik vir grappige stories oor myself nie.

$\begin{array}{lllllll}1 & 2 & 3 & 4 & 5 & 6 & 7\end{array}$

10. As ek omgekrap of ongelukkig is, dink ek gewoonlik aan iets snaaks in die situasie om myself op te beur.

$\begin{array}{lllllll}1 & 2 & 3 & 4 & 5 & 6 & 7\end{array}$

11. Ek gee nie baie om oor hoe mense my grappies of sêgoed opneem nie.

12. Ek spot dikwels met my eie swakhede, foute of flaters met die doel om meer aanvaarbaar te wees of ander meer van my te laat hou.

$\begin{array}{lllllll}1 & 2 & 3 & 4 & 5 & 6 & 7\end{array}$

13. Ek lag en maak dikwels pret saam met my vriende.

$\begin{array}{lllllll}1 & 2 & 3 & 4 & 5 & 6 & 7\end{array}$

14. My humoristiese uitkyk op die lewe help my om nie té omgekrap of depressief oor dinge te raak nie.

15. Ek hou nie daarvan dat humor gebruik word om ander te kritiseer of te verkleineer nie.

16. Ek sê nie dikwels snaakse goed om myself te verkleineer nie.

17. Ek vertel nie gewoonlik grappies of skerts saam met ander nie. 
18. As ek alleen is en ongelukkig voel, probeer ek hard om aan iets snaaks te dink om my op te vrolik.

19. Soms dink ek aan iets wat só snaaks is dat ek dit móét sê, selfs al is dit heeltemal onvanpas in die situasie.

20. Ek gaan dikwels te ver in die verkleinering van myself as ek grappies vertel of probeer snaaks wees.

21. Dis vir my lekker om mense te laat lag.

$\begin{array}{lllllll}1 & 2 & 3 & 4 & 5 & 6 & 7\end{array}$

22. As ek treurig of omgekrap voel, verloor ek gewoonlik my sin vir humor.

$\begin{array}{lllllll}1 & 2 & 3 & 4 & 5 & 6 & 7\end{array}$

23. Ek lag nooit vir ander nie, selfs al doen almal in die geselskap dit.

24. As ek in geselskap van vriende of familie is, lyk dit dikwels of ék die een is met wie ander spot of oor grappies maak.

25. Ek skerts nie dikwels saam met my vriende nie.

26. Ek ondervind dat om oor 'n prettige aspek van 'n situasie te dink 'n baie effektiewe manier is om probleme te hanteer.

27. As ek nie van mense hou nie, gebruik ek dikwels humor of terg hulle om hulle te verkleineer.

28. As ek probleme het of ongelukkig voel, steek ek dit dikwels weg agter 'n rookskerm van grappies sodat selfs my beste vriende nie kan raai hoe ek regtig voel nie. 
29. Ek kan gewoonlik nie dink aan pittige dinge om te sê as ek saam met ander mense is nie.

30. Selfs as iets vir my baie snaaks is, sal ek nie daaroor lag of grappies maak as dit iemand anders sal krenk nie.

31. Selfs as iets vir my baie snaaks is, sal ek nie daaroor lag of grappies maak as dit iemand anders sal krenk nie.

32. Om ander toe te laat om ten koste van my te lag, is my manier om my vriende en familie op te beur.

\section{Puntetoewysing}

Sosiale humor: $1^{*}, 5,9^{*}, 13,17^{*}, 21,25^{*}, 29^{*}$

Selfversterkende humor: $2,6,10,14,18,22^{*}, 26,30$

Aggressiewe humor:

$3,7^{*}, 11,15^{*}, 19,23^{*}, 27,31^{*}$

Selfverkleinerende humor:

$4,8,12,16^{*}, 20,24,28,32$

\section{Opmerkings:}

- Items wat met * aangedui is, is reversiewe items, bv. 1=7, 2=6, 3=5, 4=4, $5=3,6=2,7=1$

- Nadat items omgekeer is, kan die totaal van al 8 items in elke skaal bereken word om skaaltotale te kry.

\section{Interpretasie:}

Sosiale humor: neiging om humor met ander te deel, grappies en prettige stories te vertel, ander te vermaak, hulle te laat lag, geniet om saam met ander te lag.

Selfversterkende humor: neiging om 'n humoristiese uitkyk op die lewe te behou selfs as jy nie in die geselskap van ander is nie, gebruik humorsin om spanning te hanteer, vrolik jouself op met humor.

Aggressiewe humor: neiging om humor te gebruik om af te kraak en te verkleineer of te manipuleer; gebruik van spot, krenkende humor, kompulsiewe uitdrukking van humor selfs as dit nie paslik is nie. 
Selfverkleinerende humor: neiging om ander te amuseer tot nadeel van jouself, selfkrenkende humor; saamlag as met jou gespot word of jy verkleineer word, die gebruik van humor om jou ware gevoelens vir jouself en ander weg te steek. 